International Research Journal of Management, IT \& Social Sciences
Available online at https://sloap.org/journals/index.php/irjmis/
Vol. 6 No. 4, July 2019, pages: 54 61
ISSN: 2395-7492
https://doi.org/10.21744/irjmis.v6n4.642

\title{
A Comparative Study on Domestic and Foreign Equity Funds in
} Indonesia

I Gst Ngr Putu Adi Suartawan ${ }^{\text {a }}$
Luh Gede Sri Artini

2395-7492@ Copyright 2019. The Author. This is an open-access article under the CC BY-SA license (https://creativecommons.org/licenses/by-sa/4.0/) All rights reserved.

\author{
Author correspondence: \\ I Gst Ngr Putu Adi Suartawan, \\ Faculty of Economics and Business, Udayana University, Denpasar, Indonesia \\ Jalan P.B. Sudirman, Dangin Puri Kelod, Denpasar, Bali 80234 \\ Email address: adiign8@gmail.com
}

\section{Introduction}

Stock equity funds are one of the most popular equity funds because investors can offer higher returns compared to other types of equity funds. Along with the ability to generate high returns, stock equity funds are also accompanied by high risks, so that the valuation of yields on the risk of equity funds is very important to do (risk-adjusted return). Based on this, it is important for investors to get to know the investment company to be chosen. Various factors can

\footnotetext{
${ }^{a}$ Faculty of Economics and Business, Udayana University, Denpasar, Indonesia ${ }^{\mathrm{b}}$ Faculty of Economics and Business, Udayana University, Denpasar, Indonesia
} 
support an equity fund company that is said to be good, including having a good reputation, background and experience, historical performance (profile risk and return), investment style, company group support, the number of assets managed and a number of customers, quality of resources and quality service.

The performance evaluation of stock equity funds is very important for investors to choose and compare stock equity funds that are able to provide optimal benefits. Markovic \& Kuzner (2015); Jaksic et al., (2015) and Mamta \& Ojha (2017) stated that one method that can be used to measure the performance of stock equity funds is the Treynor index. The use of the Treynor index is based on the assumption that a portfolio is very diversified. Treynor index measurement uses systematic risk (measured by beta) so that it is right to be used to measure the performance of equity funds consisting of a collection of stocks that have been well diversified. If it has been well diversified, the unsystematic risk will be minimized, so that it only focuses on systematic risk.

Research by Khan et al., (2016), shows the majority of equity funds in Oman have a positive Treynor Index that shows very good performance even in uncertain environments. Research by Markovic \& Kuzner (2015), compares the performance of equity funds managed by foreign and domestic companies in Slovenia. The results showed that, based on the Treynor index, the performance of foreign companies was better than domestic companies. Unlike the research conducted by Zainul et al., (2014) and Utami \& Artini (2018), conducted in Indonesia, show that there is no difference in performance between foreign and domestic companies.

The ability of investment companies to manage stock equity funds in addition to the performance of the Treynor index can also be seen from the two main components, namely stock selection and market timing (Fama, 1972). Stock selection is related to the ability of investment management companies to choose the right stocks to be included or issued from equity fund portfolios so as to provide a better rate of return on market returns and to improve the performance of the stock equity fund itself (Alexandri, 2015). Market timing is related to the extent of the ability of investment companies to take advantage of market time, namely when it's time to buy securities and when to sell them again (Chen et al., 2013). The use of market timing and stock selection is based on reasons for changing time periods and market conditions so that when managing stock equity funds each company will take these steps to obtain an optimal rate of return for investors (Aggarwal, 2017; Dewi et al., 2017).

Research conducted by Sundar \& Irisappane (2015); Alexandri (2015); and Pandow (2017), shows that stock selection has a positive and significant effect on equity fund performance, while research by Rachmah \& Juniar (2018), shows that stock selection does not affect the performance of equity funds. Neto et al., (2017), shows that the average equity fund in Portugal is not able to identify the right stock (stock selection). Research by Kharisma \& Isdaryadi (2017), in Indonesia shows that only 2 (two) stock equity funds have stock selection capabilities from the 15 (fifteen) stock equity funds studied, similar to the research conducted by Panjaitan (2012), which found only 2 (two) equity funds that have stock selection capabilities.

Kim \& Sohn (2013) and Liao et al., (2017), in their research, show that companies have good market timing capabilities, respectively in Korea and China. Alexandri (2015); Pandow (2017); and Chen et al., (2013), found that market timing did not affect the performance of equity funds, where this condition illustrates that companies do not need the expertise to enter the market when they want to buy or sell securities. Research Dwiyana et al., (2017) and Kharisma \& Isdaryadi (2017), show that none of the investment companies in Indonesia have market timing capabilities. Ramayanti \& Purnamasari (2018), found that as many as 11 (eleven) investment equity fund companies have market timing capabilities.

Investors must choose investment companies that have good performance in equity funds so they can benefit from the managed portfolio (Cakrie, 2013). With the increasing and growing number of equity funds and companies in Indonesia, both domestic and foreign companies, investors are faced with many choices so that information on strategies for choosing equity funds is very important and needed for investors.

An interesting phenomenon about investment companies that manage equity funds in Indonesia is that 16 (sixteen) foreign investment companies control around 59\% of equity fund managed funds at the end of 2013. This dominance is inseparable from the behavior of Indonesian investors who prefer to invest in foreign companies than companies domestic because they are considered more experienced through knowledge about the equity fund industry (Kustina et al., 2018).

Several research results related to the performance of equity funds and the ability of the market timing and stock selection companies showed different results, so that the research gap for the research was carried out again, in addition to research on the performance comparison of domestic and foreign equity funds seen from the ability of market timing and stock selection still rarely done. This research is a comparative study that compares the performance of stock equity funds, the ability of market timing and stock selection of domestic and foreign companies in Indonesia with the

Suartawan, I. G. N. P. A., \& Artini, L. G. S. (2019). A comparative study on domestic and foreign equity funds in Indonesia. International Research Journal of Management, IT and Social Sciences, 6(4), 54-61. https://doi.org/10.21744/irjmis.v6n4.642 
aim of whether the performance of stock equity funds managed by domestic and foreign companies is the same or different.

\section{Literature Review \& Hypotheses Development}

\section{Comparison of Performance of Equity funds for Domestic and Foreign Company Shares}

Analysis of the performance of equity funds is a stage that must be considered by investors before investing. One indicator to analyze the performance of equity funds is the success of the company's strategy in managing equity fund portfolios reflected in Net Asset Value (NAV). Research by Otten \& Bams (2007), in the United States, examines the performance comparison of domestic (United States) and foreign (UK) equity funds. The results of the study show that British companies invest more in smaller companies than US companies, and there are no significant differences that distinguish the performance of domestic companies with foreign companies. Markovic \& Kuzner (2015), in his research in Slovenia, showed that based on the Treynor index, the performance of foreign companies was better than domestic companies.

Another study was also conducted by Deasy \& Sihombing (2013); Aditya et al., (2019), to determine the performance of stock equity funds in Indonesia managed by local companies and foreign companies. Using the Treynor method, out of 4 equity funds that were outperformed in that period, all of them were equity funds managed by local companies. Wibowo \& Hanafi (2017), in their research, showed that stock equity funds managed by foreign companies always ranked first in the rankings of the performance ratings performed. Performance appraisal based on the Treynor index and the level of consistency of ratings indicates that the equity funds of foreign companies are better than those of domestic companies. Based on this explanation, the hypothesis proposed is as follows:

Hla: The performance of equity funds of foreign companies is significantly better than the performance of equity funds of domestic companies seen from the Treynor Index.

Market timing is related to the extent of the ability of investment companies to take advantage of market time, namely when it's time to buy securities and when to sell them again (Chen et al., 2013). Research conducted by Kim \& Sohn (2013) and Liao (2017), shows that companies have good market timing capabilities, which proves that the company has the ability to predict markets that are good in situations of ups and downs.

Research conducted by Waelan (2008), shows that, of the 3 (three) equity fund companies that have market timing capabilities, 2 (two) of them are foreign companies. This is related to the active steps taken by equity fund management companies to optimize the returns obtained so that the average stock equity funds managed by foreign companies succeed in taking the right time in terms of when to sell and when to buy. Based on this explanation, the hypothesis proposed is as follows:

HIb:Equity fund shares of foreign companies are significantly better compared to equity funds from domestic companies seen from the ability of market timing.

Stock selection is related to the ability of investment management companies, in this case, the company to choose the right stocks to be included or excluded from the equity fund portfolio, so as to provide a better rate of return on market returns and improve the performance of the stock equity fund (Alexandri, 2015). Research conducted by Sundar \& Irisappane (2015); Alexandri (2015); and Pandow (2017), shows that stock selection has a positive and significant effect on the performance of equity funds. The selection of the right stocks and in a bullish condition in the future will be able to bring a high return.

The research conducted by Gi \& Setiawan (2017), shows that out of 7 (seven) companies that have stock selection capabilities, 4 (four) of them are foreign companies. Foreign companies have more complete information so that when carrying out the analysis and the decision to elect shares that will be included and issued in the stock equity fund portfolio can be done properly than the domestic companies. Based on this explanation, the hypothesis proposed is as follows:

H1c: Equity fund shares of foreign companies are significantly better compared to equity funds from domestic companies seen from the ability of stock selection. 


\section{Materials and Methods}

This research was designed with a quantitative approach. Quantitative research will examine the relationship between variables measured numerically and analyzed using statistical techniques. This study examines the performance comparison of stock equity funds managed by domestic companies and foreign companies. The scope of the research is equity funds registered with the Indonesian Financial Services Authority (OJK). The data analysis method used in this study is the Mann-Whitney U Test to analyze the comparison of the performance of stock equity funds seen from the Treynor Index, market timing and stock selection. The Mann-Whitney U test was conducted to determine whether there were differences in the mean for independent samples.

\section{Results and Discussions}

\subsection{Comparison of Domestic and Foreign Stock Equity funds in Indonesia Viewed from the Treynor Index}

Comparison of stock equity funds of domestic and foreign investment companies in Indonesia as seen from performance based on the Treynor index during the 2016-2018 period is shown in Table 1.

Table 1

Mann Whitney Treynor Index testing result

\begin{tabular}{llc}
\hline & Mann Whitney U Test & \\
\hline $\mathrm{N}$ & Domestic & 114 \\
& Foreign & 75 \\
Mean rank & Total & 189 \\
& Domestic & 87,89 \\
Asymp. Sig & Foreign & 105,81 \\
Seng & & 0,028 \\
\hline
\end{tabular}

Secondary Data, 2019

Based on Table 1 it can be seen that the significance value is $0.028(<0.050)$ which indicates that there are significant differences in the performance of equity funds of domestic and foreign stocks in Indonesia as seen from the Treynor index during the period 2016-2018, so H1a is accepted. The mean rank of equity fund shares of domestic investment companies of 87.89 has a smaller value than the mean rank of equity fund shares of foreign investment companies with a value of 105.81 so that the performance of equity fund shares of foreign companies is significantly better than those of domestic investment companies in Indonesia during 2016 -2018 seen from the Treynor index.

\subsection{Comparison of Domestic and Foreign Stock Equity funds in Indonesia Viewed from Market Timing Capabilities}

Comparison of stock equity funds of domestic and foreign investment companies in Indonesia based on market timing capabilities during the 2016-2018 period is shown in Table 2.

Table 2

Mann Whitney Market Timing testing result

\begin{tabular}{lll}
\hline & Mann Whitney U Test & \\
\hline $\mathrm{N}$ & Domestic & 114 \\
& Foreign & 75 \\
Mean rank & Total & 189 \\
& Domestic & 88,08 \\
Asymp. Sig & Foreign & 105,52 \\
Pryn & & 0,032 \\
\hline
\end{tabular}

Primary Data, 2019

Suartawan, I. G. N. P. A., \& Artini, L. G. S. (2019). A comparative study on domestic and foreign equity funds in Indonesia. International Research Journal of Management, IT and Social Sciences, 6(4), 54-61. https://doi.org/10.21744/irjmis.v6n4.642 
The test results in Table 2 show that the significance value is $0.032(<0.050)$ so $\mathrm{H} 1 \mathrm{~b}$ is accepted. The performance of equity funds for domestic and foreign investment companies in Indonesia is significantly different from the ability of market timing. The mean rank of a domestic investment company stock equity fund of 88.08 has a smaller value than the mean rank of an equity fund company of a foreign investment company with a value of 105.52 which indicates that the market timing ability of foreign investment companies is significantly better than that of domestic investment companies during the 2016-2018 period.

\subsection{Comparison of Domestic and Foreign Stock Equity funds in Indonesia Viewed from Stock Selection Capabilities}

Comparison of stock equity funds of domestic and foreign investment companies in Indonesia seen from the ability of stock selection during the 2016-2018 period is shown in Table 3 .

Table 3

Mann-Whitney U Stock Selection testing result

\begin{tabular}{llc}
\hline & Mann Whitney U Test & \\
\hline $\mathrm{N}$ & Domestic & 114 \\
& Foreign & 75 \\
Mean rank & Total & 189 \\
& Domestic & 101,60 \\
& Foreign & 84,97 \\
\hline
\end{tabular}

Secondary Data, 2019

The test results in Table 3 show that the significance value is $0.041(<0.050)$ so that there is a significant difference between the performance of equity funds of domestic and foreign investment companies in Indonesia seen from the ability of stock selection. The mean value of equity fund shares of domestic companies is 101.60 , which is greater than the mean rank of equity fund companies of foreign investment companies which is 84.97 , which means that the stock selection ability of domestic investment companies' equity funds is significantly better than that of 2016-2018, so H1c is rejected.

The comparison of the performance of stock equity funds seen from the Treynor index shows that equity fund shares of foreign companies have a significantly better performance than the equity funds of domestic companies. The findings in this study support the results of Smirnova \& Sprenger's (2009); Markovic \& Kuzner (2015); and Wibowo \& Hanafi (2017). Investment managers in foreign investment companies are considered more skilled in predicting returns on the basis of public information by considering systematic risk and have better experience and knowledge of the equity fund industry.

Based on the ability of market timing, equity fund shares of foreign companies have a significantly better performance than equity funds from domestic companies. Investment managers in foreign companies' stock equity funds have active steps and technical capabilities in managing equity funds to optimize the return obtained so that the average stock equity fund managed by a foreign company manages to take the right time in terms of when to sell and when to buy (Waelan, 2008).

Kim \& Sohn (2013) and Liao (2017), point out the importance of the ability of a good market timing to predict a good market in a situation of going up or down. The more positive and significant value of market timing shows that investment managers have superior market timing capabilities (Rijwani, 2014). As many as 6 (six) stock equity funds of domestic investment companies that have positive and significant market timing capabilities, while 4 (four) stock equity funds of foreign investment companies have positive and significant market timing capabilities, but have a higher value than domestic equity fund investment companies during the study period.

The comparison of the performance of stock equity funds seen from the ability of stock selection shows that the equity funds of domestic companies have a better performance than the equity funds of foreign companies. This study supports the research of Cakrie (2013) and Utami \& Artini (2018). The research findings show that investment managers in domestic stock equity fund companies have more complete information so that when conducting analysis and the decision to make a stock selection that will be included and issued in the stock equity fund portfolio can be done correctly than the investment manager in the equity fund company shares that manage stock equity funds in Indonesia. Domestic stock equity fund companies will be better able to recognize and understand the background of domestic stocks that will be included in the stock equity fund portfolio. 
Positive and significant stock selection values indicate that equity funds can produce a greater return than market returns (Paramita et al., 2018). As many as 3 (three) domestic investment company stock equity funds that have a positive and significant stock selection capability, while only 1 (one) foreign investment company shares have a positive and significant stock selection capability during the study period.

\section{Conclusion}

For investors, this study shows that when viewed from the performance using the Treynor index and market timing capabilities, the equity funds that are worthy of being an investment choice are the shares of foreign companies, while when viewed from portfolio diversification through the ability of stock selection, what should be selected is company stock equity funds domestic. For equity fund companies, it is expected to be able to help increase the growth of stock equity funds and need to make improvements in terms of performance, especially for performance that shows negative numbers, so as to produce optimal returns while taking into account the level of risk that might occur. For further research, it is expected to be able to compare the performance of other types of equity funds such as money market, protected, fixed income and mixed equity funds by using other equity fund performance measurements and other benchmarks to provide a broader picture of the condition of equity fund developments in Indonesia.

\section{Research Limitations}

This study only takes samples of outperforming stock equity funds that submit reports to OJK (Financial Services Authority), so that for further research, stock equity fund sampling can be done through cash (online sites that contain information about the best stock equity funds) and not only compare the performance of stock equity funds. but it can also compare participation units and equity fund size units. This research uses CSPI (Composite Stock Price Index) as a benchmark. Other indices can be used such as LQ 45 and Kompas 100. Comparisons made in this study are limited to stock equity funds of domestic and foreign investment companies so that further research can use other types of equity funds as comparisons such as money market equity funds, protected equity funds, fixed income equity funds or mixed equity funds.

Conflict of interest statement and funding sources

The authors declared that they have no competing interest.

Statement of authorship

The authors have a responsibility for the conception and design of the study. The authors have approved the final article.

\section{Acknowledgments}

The authors would like to thank the Editor of IRJMIS for their valuable time, support, and advice in completing the current study.

Suartawan, I. G. N. P. A., \& Artini, L. G. S. (2019). A comparative study on domestic and foreign equity funds in Indonesia. International Research Journal of Management, IT and Social Sciences, 6(4), 54-61. 


\section{References}

Aditya, A. G. D., \& Kusuma, M. G. W. (2019). The effect of tri hita karana culture in relationship between work stress and internal auditor performance. International Research Journal of Management, IT and Social Sciences, 6(2), 72-78. https://doi.org/10.21744/irjmis.v6n2.610

Aggarwal, R. (2017). Different avenues of capital market (secondary market) available for investing in market of yamuna nagar. International Research Journal of Management, IT and Social Sciences, 4(3), 34-50.

Alexandri, M. B. (2015, May). Mutual Fund Performance: Stock Selection or Market Timing. In International Conference on Economics and Banking (iceb-15). Atlantis Press.

Amalia, D., \& Sihombing, P. (2013). Analisis Kemampuan Stock Selection Dan Market Timing Pada Reksa Dana Saham Di Indonesia Periode Januari 2008-Juli 2013. Journal of Capital Market and Banking, 2(2).

Cakrie, D. T. (2013). Perbandingan kinerja investasi pada reksadana saham yang dikelola oleh manajer investasi lokal dan asing di indonesia(Doctoral dissertation, Universitas Gadjah Mada).

Chen, D., Gan, C., \& Hu, B. (2013). An empirical study of mutual funds performance in China. Available at SSRN 2220323.

Dewi, I. G. A. A. O., \& Dewi, I. G. A. A. P. (2017). Corporate social responsibility, green banking, and going concern on banking company in Indonesia stock exchange. International Journal of Social Sciences and Humanities, 1(3), 118-134. https://doi.org/10.29332/ijssh.v1n3.65

Fama, E. F. (1972). Components of investment performance. The Journal of finance, 27(3), 551-567.

GI, M. Z. (2017). Analisis kinerja reksadana berdasarkan kemampuan market timing dan stock selection manajer investasi pada periode januari 2008 “desember 2015 (Doctoral dissertation, Universitas Gadjah Mada).

Jakšić, M., Leković, M., \& Milanović, M. (2015). Measuring the performance of mutual funds: A case study. Industrija, 43(1), 37-51.

Khan, K., Jamil, S., \& Uddin, M. A. (2016). Performance evaluation of mutual funds in Oman: An investors' perspective.

Kharisma, A. W., \& Isdaryadi, F. W. (2017). Evaluasi kemampuan manajer investasi reksadana saham berdasarkan market timing dan stock selection skill.

Kim, S., \& Sohn, P. (2013). Market Timing Performance in the Korean Fund Market: Evidence from Portfolio Holdings. Procedia Economics and Finance, 5, 443-452. https://doi.org/10.1016/S2212-5671(13)00052-X

Kustina, K. T., Dewi, I. G. A. A. O., Prena, G. D., \& Utari, I. G. A. D. (2018). MSMEs credit distribution and nonperforming loan towards banking companies profit in Indonesia. International Journal of Social Sciences and Humanities, 2(1), 10-23. https://doi.org/10.29332/ijssh.v2n1.72

Liao, L., Zhang, X., \& Zhang, Y. (2017). Mutual fund managers' timing abilities. Pacific-Basin Finance Journal, 44, 80-96. https://doi.org/10.1016/j.pacfin.2017.06.003

Markovic-Hribernik, T., \& Kuzner, A. (2013). Mutual Fund Management Performance In Transition Countries: Domestic Vs. Foreign Mutual Fund Managers-Research Findings For Slovenia. Romanian Economic and Business Review, 8(4), 85.

Neto, N. M. V., Lobão, J. F. S. S. D. M., \& Vieira, E. S. (2017). Do Portuguese mutual funds display forecasting skills? A study on selectivity and market timing ability. Studies in Economics and Finance, 34(4), 597-631. https://doi.org/10.1108/SEF-09-2015-0233

Ojha, S. C. (2017). Performance Evaluation of Mutual Funds: A Study of Selected Equity Diversified Mutual Funds in India.

Otten, R., \& Bams, D. (2007). The performance of local versus foreign mutual fund managers. European financial management, 13(4), 702-720. https://doi.org/10.1111/j.1468-036X.2007.00379.x

Pandow, B. (2017). Persistent Performance of Fund Managers: An analysis of selection and timing skills. International Journal of Commerce and Finance, 3(2), 11-24.

Panjaitan, M. V. (2012). Analisis Kemampuan Stock Selection dan Market Timing Manajer Investasi Pada Reksadana Saham di Indonesia. Jurnal Ilmiah Mahasiswa Manajemen, 1(2).

Paramita, V. S., Sembiring, F. M., \& Safitri, D. (2018). Measuring Selectivity and Market Timing Performance of Mutual Funds in Indonesia Using Single and Dual Beta Models. KnE Social Sciences.

Rachmah, D. A., \& Juniar, A. (2018). Analisis pengaruh stock selection skill, market timing ability, dan fund longevity terhadap kinerja reksa dana saham syariah. jurnal sains manajemen dan kewirausahaan, 2(1), 61-69.

Ramayanti, T. P., \& Purnamasari, K. (2018). Kemampuan Pemilihan Saham dan Penetapan Waktu Pada Manajer investasi Reksa Dana Saham di Indonesia. Esensi: Jurnal Bisnis dan Manajemen, 8(1). 
Rijwani, P. (2014). Stock Selection, Market Timing and Mutual Fund Performance. Indian Journal of Accounting, 46(2), 47-58.

Smirnova, G., \& Sprenger, C. Do locals perform better than foreigners: evidence from mutual funds investing in Russia.

Sundar, V., \& Irisappane, A. (2015). " Stock selection abilities and the market timing skills of fund Managers": A study with reference to banking sector funds in India. International Journal of Information, Business and Management, 7(4), 186.

Utami, A. A. P., \& Artini, L. G. S. (2018). Komparasi reksadana saham perusahaan investasi nasional dan asing di indonesia dilihat dari kinerja, market timing dan stock selection. E-Jurnal Ekonomi dan Bisnis Universitas Udayana, 7, 649-678.

Waelan, W. (2008). Kemampuan Memilih Saham dan Market Timing Manajer Investasi Reksa Dana Saham di Bursa Efek Indonesia. Indonesian Journal of Accounting and Auditing, 12(2).

Wibowo, N. H. (2017). Analisis perbandingan kinerja reksadana saham manajer investasi domestik dan reksadana saham manajer investasi asing periode 2013-2015 dengan menggunakan metode indeks sharpe, indeks treynor dan indeks jensen (Doctoral dissertation, Universitas Gadjah Mada).

Yana, M. D., Riwajanti, N. I., \& Setiati, F. (2017). Analisis Securities Selection Skill dan Market Timing Ability Pada Kinerja Reksadana Syariah Campuran Di Bursa Efek Indonesia. Jurnal Riset dan Aplikasi: Akuntansi dan Manajemen, 2(3), 215-224.

Zainul, Z. R. Analisis Perbandingan Kinerja Reksadana Saham yang Dikelola Perusahaan Investasi Lokal dan Asing di Indonesia (Master's thesis).

\section{Websites}

www.bi.go.id.

www.economy.okezone.com.

www.reksadana.ojk.go.id

www.yahoofinance.com.

Suartawan, I. G. N. P. A., \& Artini, L. G. S. (2019). A comparative study on domestic and foreign equity funds in Indonesia. International Research Journal of Management, IT and Social Sciences, 6(4), 54-61. 